УДК 311: 338.27

JEL: C20, E01

\author{
Заєць Світлана Володимирівна \\ кандидат економічних наук, доцент, \\ доцент кафедри статистики та демографії, \\ Київський національний університет імені Тараса Шевченка, \\ Київ, Україна \\ ORCID ID: 0000-0002-6133-1087 \\ e-mail: zsv@bigmir.net
}

\title{
СТАТИСТИЧНЕ ПРОГНОЗУВАННЯ ПОКАЗНИКІВ РІВНЯ ЖИТТЯ НАСЕЛЕННЯ В КОНТЕКСТІ СТАЛОГО РОЗВИТКУ
}

Анотація. В статті досліджено сутність і значення прогнозування основних показників рівня життя населення для формування стійкого економічного розвитку країни.

Статистичне прогнозування рівня життя населення $є$ інформаційною базою для визначення цілей та напрямів соціально-економічного розвитку країни, розроблення орієнтовних макроекономічних параметрів та їх обгрунтування, а також прийняття управлінських рішень щодо досягнення бажаного рівня життя населення.

Вихідною базою для прогнозування рівня життя населення, визначення основних напрямів розвитку країни є запропонована система статистичних показників рівня життя населення України за 2010-2019 рр. Основними з них є такі макроекономічні показники, як: валовий внутрішній продукт в розрахунку на душу населення, індекс інфляції, середня тривалість життя, індекс людського розвитку, тощо.

Методологічною основою дослідження є широко відомий метод кореляційно-регресійного аналізу. Регресійний аналіз проведено на основі побудованих рівнянь тренду для кожної із досліджуваних залежних змінних величин. Зокрема, статистичною базою для прогнозування рівня життя населення в контексті сталого економічного розвитку стали два ключові макроекономічні індикатори - валовий внутрішній продукт у розрахунку на одного зайнятого та оплата праці найманих працівників у розрахунку на одного зайнятого. Обгрунтовано доцільність статистичного прогнозування цих індикаторів для дослідження перспектив розвитку рівня життя в країні.

Валовий внутрішній продукт відображає стан економіки в державі і використовується для оцінки результатів виробництва та споживання, темпів економічного зростання, продуктивності праці, а також формує уявлення про загальний матеріальний добробут населення. Рівень заробітної плати як соціальноекономічна категорія є основним джерелом доходів зайнятого населення і значною мірою характеризує матеріальний стан членів суспільства.

Практичні результати прогнозування рівня життя є основою для обгрунтування та прийняття управлінських рішень щодо подальшого соціально-економічного розвитку країни. Визначено довірчі межі, в яких буде знаходитися обсяг валового внутрішнього продукту в розрахунку на одного зайнятого та оплата праці найманих працівників у розрахунку на одного зайнятого в Україні у 2020 р.

Сьогодні в умовах невизначеності і швидких змін внутрішнього та зовнішнього середовища важливо передбачати можливі варіанти розвитку ключових показників рівня життя населення та вміти упередити настання можливих небажаних наслідків і тенденцій світової пандемії, що мала свій початок у 2020 році.

Ключові слова: рівень життя; якість життя; добробут; валовий внутрішній продукт; оплата праці; прогнозування; регресійний аналіз; кореляційний аналіз.

DOI: http://doi.org/10.32750/2020-0212

\section{ВСТУП}

Найголовнішою метою соціально-економічного розвитку будь-якої соціальної держави $є$ забезпечення зростання рівня життя населення. Рівень життя як вагома компонента людського розвитку $є$ узагальненим відображенням стану економічного розвитку суспільства і вимагає всебічного аналізу та багатовимірного підходу. 
В Ініціативі «Краще життя» Організації економічного співробітництва та розвитку (ОЕСР) [1], окреслено три підходи до розуміння та вимірювання добробуту людей:

- матеріальні умови життя (або економічний добробут), що визначають споживання людей, їх здатності до управління цими ресурсами;

- якість життя, що охоплює сукупність негрошових атрибутів фізичних осіб, які формують їхні можливості та життєві шанси, і мають внутрішню цінність у різних культур та різні контексти.

- стійкість соціально-економічних і природних систем, в яких живуть люди, і які залежні від впливу поточної людської діяльності на запаси різних видів (природних, економічних, людських та соціальних) ресурсів, що складають основу добробуту.

Отже, визначення параметрів майбутнього має грунтуватися на використанні методичного інструментарію стратегічного планування, на дослідженні та прогнозуванні індикаторів рівня життя населення, що $є$ пріоритетним напрямом державної політики, спрямованої на сталий економічний розвиток країни.

Постановка проблеми. Забезпечення розвитку країни, добробуту іï населення потребують проведення державної політики, націленої на передбачення напрямів розвитку на підвищення рівня життя громадян. Сьогодні необхідно вміти адаптуватися до поточної ситуації у світі та підтримувати гідний рівень життя громадян. Забезпечення достатнього рівня достовірності прогнозних розрахунків ключових індикаторів рівня життя населення є необхідною умовою для забезпечення сталого розвитку суспільства.

Аналіз останніх досліджень i публікацій. Проблемами дослідження прогнозування макроекономічних показників рівня життя та добробуту населення займаються багато вчених, зокрема такі як: Кулинич Р. О. [2], Єріна А. М., Пальян 3.О., [3], Ковтун Н. В. [4], Лібанова Е. М., Манцуров І. Г., Герасименко С. С. та інші. Проте сьогодні відчувається недостатність теоретичних та методичних положень статистичного вивчення аспектів прогнозування показників рівня життя населення в контексті сталого економічного розвитку, в результаті чого виникає необхідність подальших наукових досліджень у цьому напрямі.

Мета статті. Метою дослідження $є$ розроблення параметрів прогнозованих макроекономічних показників рівня життя та соціально-економічного розвитку України, їх обгрунтування на основі регресійних моделей тренду, а також прийняття управлінських рішень.

\section{РЕЗУЛЬТАТИ ДОСЛІДЖЕННЯ}

Сьогодні в умовах пандемії вкрай важливо проаналізувати різні сценарії розвитку країни для вироблення шляхів і пошуку можливих резервів стабілізації економіки та підтримання гідного рівня життя населення, збереження позитивних тенденцій.

Результати прогнозування $є$ вихідною базою для прийняття науково обгрунтованих управлінських рішень у галузі державної політики у площині побудови нових потужностей теоретичного концепту розробки стратегії модернізації економічного розвитку та підвищення рівня життя населення країни.

Для прогнозування показників, що характеризують різноманітні аспекти рівня життя населення (обсяг валового внутрішнього продукту, середній рівень заробітної плати, індекс споживчих цін, середня тривалість життя, обсяг реалізованої промислової продукції на душу населення тощо) використовують різні методи (статистичні, зокрема кореляційно-регресійний аналіз, функціонально-ієрархічні, методи структурної аналогії, імітаційне моделювання, експертні оцінки та ін.).

Категорія «рівень життя» формує зміст сучасних підходів до проблем забезпечення людського й сталого розвитку. В останні роки концепція людського розвитку значно 
збагатилася змістовно і трансформувалася в основу довгострокової стратегії соціальноекономічного розвитку більшості країн. Створення сприятливих можливостей для максимальної реалізації існуючого потенціалу населення в межах його потреб та інтересів визнається світовою спільнотою пріоритетною метою. При цьому основними умовами залишаються: довге та здорове життя, доступ до необхідних для забезпечення гідного рівня життя ресурсів, участь у житті суспільства.

Концептуальний підхід до людського розвитку був розроблений групою експертів Програми розвитку ООН. За індексом людського розвитку (далі - ІЛР) у 2019 р. Україна посіла 74 місце й віднесена ПРООН до країн з високим рівнем людського розвитку [5]. Досягнення ж гідного рівня людського розвитку є не лише ключовою метою, а й найбільш важливою детермінантою і чинником соціального й економічного розвитку [6].

Для аналізу й оцінки життєвого рівня населення, крім індекса людського розвитку, використовують й інші показники, такі як: валовий внутрішній продукт в розрахунку на душу населення, індекс інфляції, середня тривалість життя тощо.

Розглянемо динаміку окремих індикаторів рівня життя населення України за період 2010-2019 pp.

Таблиця 1

Індикатори рівня життя населення України у 2010-2019 рр.

\begin{tabular}{|c|c|c|c|c|c|c|}
\hline \multirow[b]{3}{*}{ Рік } & \multicolumn{6}{|c|}{ № показника } \\
\hline & 1 & 2 & 3 & 4 & 5 & 6 \\
\hline & $\begin{array}{l}\text { Індекс } \\
\text { людського } \\
\text { розвитку }\end{array}$ & $\begin{array}{lr}\text { Валовий } & \\
\text { внутрішній } & \\
\text { продукт } & \text { у } \\
\text { розрахунку на } \\
\text { одну особу (у } \\
\text { постійних цінах } \\
2010 \text { року), грн }\end{array}$ & $\begin{array}{l}\text { Середня } \\
\text { очікувана } \\
\text { тривалість } \\
\text { життя при } \\
\text { народженні, } \\
\text { років }\end{array}$ & $\begin{array}{l}\text { Індекс } \\
\text { споживчих } \\
\text { цін, грудень } \\
\text { до грудня } \\
\text { попереднього } \\
\text { року; } \\
\text { відсотків }\end{array}$ & 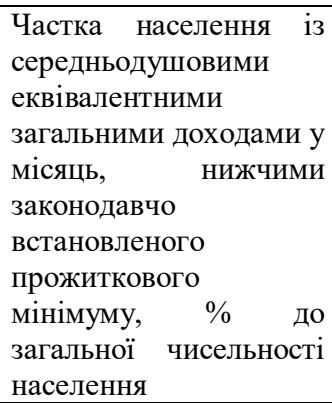 & $\begin{array}{l}\text { Частка } \\
\text { домогоспо- } \\
\text { дарств, які } \\
\text { мають доступ } \\
\text { до послуг } \\
\text { Інтернету } \\
\text { вдома, \% }\end{array}$ \\
\hline 2010 & 0,755 & 24798 & 70,4 & 109,1 & 8,6 & 22,9 \\
\hline 2011 & 0,760 & 26252 & 71,0 & 104,6 & 7,8 & 29,3 \\
\hline 2012 & 0,764 & 26385 & 71,2 & 99,8 & 9,0 & 36,1 \\
\hline 2013 & 0,767 & 26444 & 71,4 & 100,5 & 8,3 & 43,1 \\
\hline 2014 & 0,771 & 24790 & 71,4 & 124,9 & 8,6 & 48,3 \\
\hline 2015 & 0,765 & 22449 & 71,4 & 143,3 & 6,4 & 50,7 \\
\hline 2016 & 0,768 & 23090 & 71,7 & 112,4 & 3,8 & 54,0 \\
\hline 2017 & 0,771 & 23763 & 72,0 & 113.7 & 2,4 & 59,8 \\
\hline 2018 & 0,774 & 24698 & 71,8 & 109,8 & 1,3 & 61,5 \\
\hline 2019 & 0,779 & 25636 & 72,0 & 104,1 & 1,1 & 65,8 \\
\hline
\end{tabular}

Джерело: побудовано автором за даними [7 - 10].

Незважаючи на помітне зростання значення ІЛР протягом 2010-2019 років (відповідно з 0,755 до 0,779), позиція України у світовому рейтингу зі змінним успіхом поступово переміщувалася із 82 місця у 2010 році на 74 місце у 2019 році.

Складова індексу - очікувана тривалість життя при народженні $є$ нижчою, ніж у середньому серед країн групи, в яку входить Україна. Перевагою України є освітні здобутки населення, які засвідчують високий потенціал людського розвитку, повноцінна реалізація якого потребує створення сприятливих умов з боку держави.

Місце України за рівнем людського розвитку, в першу чергу, зумовлено низьким рівнем валового національного доходу в розрахунку на душу населення, за рівнем якого Україна значно поступається країнам з високим рівнем людського розвитку. 
При аналізі рівня життя країн валовий внутрішній продукт (ВВП) є узагальнюючим показником, що відображає досягнутий рівень розвитку продуктивних сил та виробничих потужностей країни за певний період часу. Разом 3 тим, обсяг ВВП відображає рівень матеріального добробуту населення для забезпечення відповідного рівня та якості життя населення країни.

3 метою визначення майбутньої динаміки зміни показників, що характеризують рівень життя населення України, були розраховані можливі варіанти рівнянь тренду (табл. 2).

Табличя 2

Показники апроксимації рівнянь тренду індикаторів рівня життя населення

\begin{tabular}{|l|l|l|l|r|}
\hline $\begin{array}{l}\text { № } \\
\text { показ- } \\
\text { ника }\end{array}$ & Назва функції & Аналітичне рівняння & $\begin{array}{l}\text { Індекс } \\
\text { кореляції }\end{array}$ & $\begin{array}{l}\text { Коефіціснт } \\
\text { детермінації }\end{array}$ \\
\hline \multirow{4}{*}{1} & Лінійна & $\hat{y}=0,0021 t+0,7559$ & 0,918 & 0,8429 \\
\cline { 2 - 5 } & Степенева & $\hat{y}=0,7544 \mathrm{t}^{0,0113}$ & 0,921 & 0,8475 \\
\cline { 2 - 5 } & Поліноміальна & $\hat{\mathrm{y}}=-5 \mathrm{E}-05 \mathrm{t}^{2}+0,0026 \mathrm{t}+0,7549$ & 0,919 & 0,8454 \\
\hline \multirow{4}{*}{2} & Лінійна & $\hat{\mathrm{y}}=-174,84 \mathrm{t}+25792$ & 0,379 & 0,1437 \\
\cline { 2 - 5 } & Степенева & $\hat{\mathrm{y}}=25902 \mathrm{t}^{-0,029}$ & 0,373 & 0,1388 \\
\cline { 2 - 5 } & Поліноміальна & $\hat{\mathrm{y}}=63,629 \mathrm{t}^{2}-874,76 \mathrm{t}+27192$ & 0,515 & 0,2655 \\
\hline \multirow{4}{*}{4} & Лінійна & $\hat{\mathrm{y}}=0,1509 \mathrm{t}+70,6$ & 0,932 & 0,8694 \\
\cline { 2 - 5 } & Степенева & $\hat{\mathrm{y}}=70,451 \mathrm{t}^{0,0091}$ & 0,972 & 0,9450 \\
\cline { 2 - 5 } & Поліномальна & $\hat{\mathrm{y}}=-0,014 \mathrm{t}^{2}+0,3051 \mathrm{t}+70,292$ & 0,958 & 0,9174 \\
\hline \multirow{3}{*}{5} & Лінійна & $\hat{\mathrm{y}}=0,697 \mathrm{t}+108,39$ & 0,160 & 0,0257 \\
\cline { 2 - 5 } & Степенева & $\hat{\mathrm{y}}=105,65 \mathrm{t}^{0,0362}$ & 0,241 & 0,0582 \\
\cline { 2 - 5 } & Поліноміальна & $\hat{\mathrm{y}}=-0,822 \mathrm{t}^{2}+9,7386 \mathrm{t}+90,303$ & 0,504 & 0,2543 \\
\hline \multirow{3}{*}{6} & Лінійна & $\hat{\mathrm{y}}=-0,98 \mathrm{t}+11,12$ & 0,916 & 0,8395 \\
\cline { 2 - 5 } & Степенева & $\hat{\mathrm{y}}=15,912 \mathrm{t}^{-0,833}$ & 0,743 & 0,5521 \\
\cline { 2 - 5 } & Поліноміальна & $\hat{\mathrm{y}}=-0,1186 \mathrm{t}^{2}+0,3242 \mathrm{t}+8,5117$ & 0,958 & 0,9181 \\
\cline { 2 - 5 } & Лінійна & $\hat{\mathrm{y}}=4,637 \mathrm{t}+21,647$ & 0,987 & 0,9748 \\
\cline { 2 - 5 } & Степенева & $\hat{\mathrm{y}}=22,142 \mathrm{t}^{0,4682}$ & 0,997 & 0,9946 \\
\cline { 2 - 5 } & Поліноміальна & $\hat{\mathrm{y}}=-0,2629 \mathrm{t}^{2}+7,5286 \mathrm{t}+15,863$ & 0,997 & 0,9948 \\
\hline
\end{tabular}

Джерело: складено автором

Обгрунтування доцільності застосування прогнозних розрахунків результативних показників у майбутньому періоді визначається обчисленими значеннями параметрів рівнянь тренду та знаками при них.

Зважаючи, що параметри рівнянь мають позитивні значення та високі рівні показників апроксимації, можливим є застосування більшості з наведених методів побудови рівнянь для прогнозування використаних показників, крім рівнянь тренду для валового внутрішнього продукту у розрахунку на одну особу та частки населення із середньодушовими еквівалентними загальними доходами у місяць, нижчими законодавчо встановленого прожиткового мінімуму. Змінюваність ситуації та комплексу умов, які відображають дані показники, не дає змогу очікувати в майбутньому ті властивості і характер зміни, які були виявлені у ретроспективі.

Результати застосування наведених підходів із використанням реальних статистичних даних показали, що оптимальними (3 наведених) виявилися моделі прогнозування за лінійним трендом. Відхилення прогнозних показників від реальних, виявлені в ході дослідження на підставі відповідних розрахунків, дають змогу стверджувати, що на зазначені показники впливають ще й інші чинники, які й внесли свій вплив на їх реальний рівень в прогнозованих періодах. 
Тому, для прогнозування змін у короткостроковій перспективі скористаємось такими показниками, як валовий внутрішній продукт в розрахунку на одного зайнятого та оплата праці найманих працівників у розрахунку на одного зайнятого.

У табл. 3 наведені вихідні дані для розрахунку параметрів рівняння лінійного тренду динамічного ряду ВВП у розрахунку на одного зайнятого за I-IV кв. 20172019 pp.

Таблиия 3

Вихідні дані для розрахунку параметрів лінійного тренду

ВВП у розрахунку на одного зайнятого

\begin{tabular}{|c|c|c|c|c|c|}
\hline Період & $\begin{array}{l}\text { Поточний } \\
\text { номер періоду, } \\
t_{i}\end{array}$ & $\begin{array}{l}\text { ВВП у розрахунку } \\
\text { на } \quad \text { одного } \\
\text { зайнятого, грн, } y_{i}\end{array}$ & $t_{i} y_{i}$ & $t_{i}^{2}$ & $\begin{array}{l}\text { Теоретичні рівні ВВП у } \\
\text { розрахунку на одного } \\
\text { зайнятого, грн, } \hat{y}_{i}\end{array}$ \\
\hline I кв. 2017 & 1 & 36674 & 36674 & 1 & 41085 \\
\hline II кв. 2017 & 2 & 41175 & 82350 & 4 & 43343 \\
\hline III кв. 2017 & 3 & 51638 & 154914 & 9 & 45601 \\
\hline IV кв. 2017 & 4 & 55200 & 220800 & 16 & 47859 \\
\hline I кв. 2018 & 5 & 43150 & 215750 & 25 & 50118 \\
\hline II кв. 2018 & 6 & 49519 & 297114 & 36 & 52376 \\
\hline III кв. 2018 & 7 & 60804 & 425628 & 49 & 54634 \\
\hline IV кв. 2018 & 8 & 64155 & 513240 & 64 & 56892 \\
\hline I кв. 2019 & 9 & 49168 & 442512 & 81 & 59151 \\
\hline II кв. 2019 & 10 & 56259 & 562590 & 100 & 61409 \\
\hline III кв. 2019 & 11 & 67067 & 737737 & 121 & 63667 \\
\hline IV кв. 2019 & 12 & 67251 & 807012 & 144 & 65925 \\
\hline Усього & 55 & 642060 & 4496321 & 650 & 642060 \\
\hline
\end{tabular}

Джерело: складено автором

3 вихідних даних табл. 3 видно, що 3 кожним роком в Україні за період 20172019 рр. відбувалось поступове зростання ВВП у розрахунку на одного зайнятого. Тому використаємо для прогнозування рівняння лінійної регресії:

$$
\hat{y}=a+b t
$$

де $\hat{y}$ - рівняння тренду лінійної функції (теоретичні значення ВВП у розрахунку на одного зайнятого);

$\boldsymbol{a}$ - початковий параметр рівняння тренду;

$\boldsymbol{b}$ - параметр рівняння тренду (характеризує середню швидкість динаміки);

$\boldsymbol{t}$ - чинникова ознака - квартал.

Параметри рівняння $a$ і $b$ знаходимо з системи рівнянь:

$$
\left\{\begin{array}{l}
a n+b \sum_{1}^{n} t_{i}=\sum_{1}^{n} y_{t} \\
a \sum_{1}^{n} t_{i}+b \sum_{1}^{n} t_{i}^{2}=\sum_{1}^{n} y_{i} t_{i}
\end{array}\right.
$$

Відповідно до встановлених у табл. 3 параметрів система нормальних рівнянь має вигляд: 


$$
\left\{\begin{array}{l}
12 a+78 b=642060 \\
78 a+650 b=4496321
\end{array}\right.
$$

Розрахунком цієї системи рівнянь будуть такі значення параметрів лінійного рівняння тренду: $a=2258,3, b=38826,3$ та функціональний вид рівняння тренду:

$$
\hat{y}=2258,3 t+38826,3
$$

Згідно з параметрами рівняння ВВП у розрахунку на одного зайнятого за досліджуваний період має тенденцію до збільшення в середньому на 2258,3 грн щоквартально.

Оцінювання параметрів рівнянь тренду здійснюється на основі кращої апроксимації за принципом мінімізації суми квадратів різниці теоретичних значень, визначених на основі рівняння тренду, від фактичних:

$$
\sum_{i=1}^{n}(y-\hat{y})^{2} \rightarrow \min .
$$

Для побудови довірчого інтервалу прогнозних значень застосуємо коригувальний коефіцієнт [ $\left.111^{\text {Error! Reference source not found. }}\right]$.

$$
Q=\left(1+\frac{1}{n}+\frac{\left(t_{i}-\bar{t}\right)^{2}}{\sum_{i=1}^{n}\left(t_{i}-\bar{t}\right)^{2}}\right)
$$

де $t$ - порядковий номер прогнозованого періоду;

$\bar{t}-$ порядковий номер $t$, що стоїть в середині ряду ;

$\boldsymbol{n}$ - довжина ряду динаміки.

Довірчі межі прогнозних рівнів ряду динаміки $\tilde{y}$ при відомих значеннях надійності $\alpha$ та пояснювальної змінної $\boldsymbol{t}_{\boldsymbol{i}}$ визначимо за формулою:

$$
\hat{y}_{i}-t_{f, \alpha} S_{\hat{y}_{i}} Q \leq \tilde{y}_{i} \leq \hat{y}_{i}+t_{f, \alpha} S_{\hat{y}_{i}} Q
$$

де $S_{\hat{y}_{i}}$ - стандартна похибка тренду, квадратний корінь із стандартного відхилення рівняння регресії;

$t_{f, \alpha}$ - критерій Стьюдента, визначений на основі заданих значень рівня імовірності $\alpha$ та кількості ступенів вільності $f=n-m-1$. Підрядковий індекс $i$ відносить величини до поточного номера кварталу, $i=1,12$.

Для встановлення довірчих меж для усіх членів ряду динаміки ВВП у розрахунку на одного зайнятого $\boldsymbol{t}_{\boldsymbol{i}} \quad(i=1,2, \ldots, 12)$ використаємо формулу стандартного відхилення. Середнє значення символів часу $\bar{t}=6,5$ р., залишкова дисперсія дорівнює

$S_{u}^{2}=\frac{401494988,4}{10}=40149498,84, n=12$ р., квантиль $t_{f, \alpha}$ розподілу Стьюдента при $\alpha=0,05$ і $f=12-1-1=10$ ступенях вільності: $t_{10 ; 0,05}=2,228$.

У табл. 4 наведено дані для встановлення меж прогнозованого ВВП у розрахунку на одного зайнятого на основі розрахунку довірчих інтервалів. 
За даними табл. 4 прогнозовані значення ВВП у розрахунку на одного зайнятого у I-IV 2020 р. будуть знаходитися в межах:

51607 грн $\leq \hat{y}_{\text {І кв.2020 }} \leq 84760$ грн;

53287 грн $\leq \hat{y}_{\text {II кв.2020 }} \leq 87597$ грн;

54907 грн $\leq \hat{y}_{\text {III кв.2020 }} \leq 90494$ грн;

56474 грн $\leq \hat{y}_{\mathrm{IV} \text { кв. } 2020} \leq 93443$ грн.

Таблиия 4

Розрахунок довірчих інтервалів для встановлення меж прогнозованого обсягу ВВП у розрахунку на одного зайнятого

\begin{tabular}{|l|c|c|c|c|c|}
\hline Період & $\begin{array}{l}\text { Поточний } \\
\text { номер } \\
\text { періоду, } \\
\boldsymbol{t}_{\boldsymbol{i}}\end{array}$ & $\begin{array}{l}\text { Теоретичне } \\
\text { значення ВВП у } \\
\text { розрахуну на } \\
\text { одного зайнятого, } \\
\text { грн, } \hat{y}_{i}\end{array}$ & $t_{10 ; 0,05} S_{\hat{y}_{i}} \mathrm{Q}$ & $\hat{y}_{i}-t_{10 ; 0,05} S_{\hat{y}_{i}} Q$ & $\hat{y}_{i}+t_{10 ; 0,05} S_{\hat{y}_{i}} \mathrm{Q}$ \\
\hline I кв. 2020 & 13 & 68183,7 & 16576,9 & 51606,8 & 84760,6 \\
\hline II кв. 2020 & 14 & 70441,9 & 17155,4 & 53286,6 & 87597,3 \\
\hline III кв. 2020 & 15 & 72700,2 & 17793,4 & 54906,8 & 90493,6 \\
\hline IV кв. 2020 & 16 & 74958,5 & 18484,9 & 56473,5 & 93443,4 \\
\hline
\end{tabular}

Джерело: складено автором

На рис. 1 представимо графічно динаміку ВВП у розрахунку на одного зайнятого поквартально у 2017-2019 pp., а також теоретичні й прогнозовані значення, визначені на основі регресійного аналізу (розрахунку рівняння тренду) на I-IV кв. 2020 р.

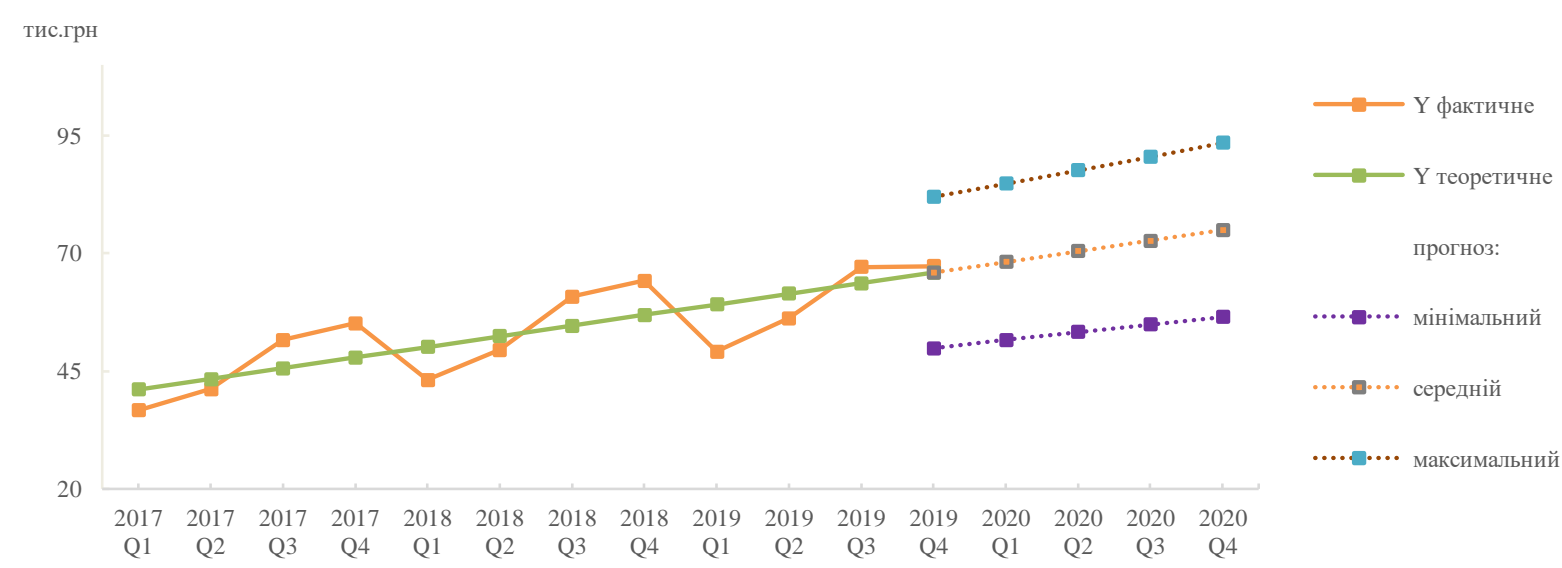

Рис. 1. Динаміка фактичного і прогнозованого обсягу валового внутрішнього продукту у розрахунку на одного зайнятого в Україні у 2017-2020 pp.

Джерело: побудовано автором

Отже, у прогнозованому періоді I-IV кв. 2020 р. очікується збільшення обсягів ВВП у розрахунку на одного зайнятого від 51607 грн до 84760 грн у I кв. 2020 р., від 53287 грн до 87597 грн у II кв. 2020 р., 54907 грн до 90494 грн у III кв. 2020 р. та від 56474 грн до 93443 грн у IV кв. 2020 р.

Таким чином, можна відзначити, що прогнозна динаміка ВВП України у розрахунку на одного зайнятого буде зростаючою. Проте у 2-3 кварталах 2020 р. можливим є зниження цього показника до рівня 2019 р. Цей сценарій не варто 
виключати, оскільки темпи зростання ВВП в останніх кварталах 2019 р. значно уповільнились.

На основі аналізу динаміки цього показника та використання ліній тренду, як інструменту його прогнозування у майбутньому, можна виділити три можливих сценарії річної перспективної динаміки ВВП у розрахунку на одного зайнятого у 2020 р в порівнянні з 2019 р.:

- оптимістичний: зростання на $50 \%$;

- середньо-очікуваний: подальше зростання темпів зміни із переважанням тенденції на деяке підвищення темпів зростання із швидкістю 19\% за рік;

- песимістичний: зменшення ВВП в середньому на $10 \%$.

Вагомим індикатором рівня життя населення $\epsilon$ динаміка оплати праці. Цей індикатор має пряме відношення до купівельної спроможності громадян. На сучасному етапі економічного розвитку заробітна плата є основним джерелом доходів населення та слугує для відтворення робочої сили та ефективного функціонування виробництва, що відповідає досягнутому рівню життя в суспільстві. У структурі доходів населення заробітна плата займає найбільшу питому вагу - 47,0\% (за даними 2019 р.) [12].

Аналогічно проведемо розрахунки для прогнозування рівня оплати праці найманих працівників у розрахунку на одного зайнятого в Україні на I-IV квартали 2020 р. та побудуємо модель лінійного тренду.

У табл. 5 наведено вихідні дані для розрахунку параметрів лінійного тренду оплати праці найманих працівників у розрахунку на одного зайнятого.

Вихідні дані для розрахунку параметрів лінійного тренду

Табличя 5

оплати праці найманих працівників у розрахунку на одного зайнятого

\begin{tabular}{|c|c|c|c|c|c|}
\hline Період & $\begin{array}{l}\text { Поточний } \\
\text { номер } \\
\text { періоду, } t_{i}\end{array}$ & $\begin{array}{lr}\text { Оплата } & \text { праці } \\
\text { найманих } & \\
\text { працівників } & \text { у } \\
\text { розрахунку } & \text { на } \\
\text { одного зайнятого, } \\
\text { грн, } y_{i}\end{array}$ & $t_{i} y_{i}$ & $t_{i}^{2}$ & $\begin{array}{lr}\text { Теретичні } & \text { рівні оплати } \\
\text { праці } & \text { найманих } \\
\text { працівників у розрахунку } \\
\text { на одного зайнятого, грн, } \\
\hat{y}_{i}\end{array}$ \\
\hline І кв. 2017 & 1 & 15559 & 15559 & 1 & 16564 \\
\hline II кв. 2017 & 2 & 18232 & 36464 & 4 & 17591 \\
\hline III кв. 2017 & 3 & 18600 & 55800 & 9 & 18617 \\
\hline IV кв. 2017 & 4 & 20072 & 80288 & 16 & 19643 \\
\hline I кв. 2018 & 5 & 19648 & 98240 & 25 & 20669 \\
\hline II кв. 2018 & 6 & 22936 & 137616 & 36 & 21696 \\
\hline III кв. 2018 & 7 & 22967 & 160769 & 49 & 22722 \\
\hline IV кв. 2018 & 8 & 24439 & 195512 & 64 & 23748 \\
\hline I кв. 2019 & 9 & 23478 & 211302 & 81 & 24774 \\
\hline II кв. 2019 & 10 & 26406 & 264060 & 100 & 25801 \\
\hline III кв. 2019 & 11 & 26590 & 292490 & 121 & 26827 \\
\hline IV кв. 2019 & 12 & 27578 & 330936 & 144 & 27853 \\
\hline Усього & 55 & 266505 & 1879036 & 650 & 266505 \\
\hline
\end{tabular}

Джерело: складено автором

Відповідно до встановлених за допомогою табл. 5 параметрів система нормальних рівнянь має вигляд:

$$
\left\{\begin{array}{l}
12 a+78 b=266505 \\
78 a+650 b=1879036
\end{array}\right.
$$


Розрахунком цієї системи рівнянь будуть такі значення параметрів лінійного рівняння тренду: $a=1026,2, b=15538,1$.

У результаті складемо рівняння тренду і обчислимо теоретичні значення оплати праці у розрахунку на одного зайнятого $\hat{y}_{i}$ в кожній з точок:

$$
\hat{y}=1026,2 t+15538,1 \text {. }
$$

Отже, оплата праці найманих працівників у розрахунку на одного зайнятого за досліджуваний період має тенденцію до збільшення в середньому на 1026,2 грн щоквартально.

Зазначене вище рівняння може бути відібране для прогнозування, оскільки коефіцієнт детермінації, що характеризує рівень впливу часу на оплату праці найманих працівників у розрахунку на одного зайнятого, складає 0,9562 .

Для розрахунку довірчого інтервалу прогнозованих значень для усіх рівнів ряду динаміки оплати праці найманих працівників у розрахунку на одного зайнятого використаємо формулу стандартного відхилення рівняння регресії, після чого із розрахованих значень вирахуємо квадратний корінь.

Середнє значення символів часу $\bar{t}=6,5$ р., залишкова дисперсія дорівнює

$S_{u}^{2}=\frac{6904361,4}{10}=690436,1, \quad n=12$ p., квантиль $t_{f, \alpha}$ розподілу Стьюдента при $\alpha=0,05$ і $f=12-1-1=10$ ступенях вільності: $t_{10 ; 0,05}=2,228$.

Сформуємо довірчі межі рівнів ряду тренду $\tilde{y}$ при відомих значеннях надійності $\alpha$ та параметру часу $t_{i}$. Результати проведених обчислень представимо у табл. 6.

Таблиия 6

Розрахунок довірчих інтервалів для встановлення меж прогнозного рівня оплати праці найманих працівників у розрахунку на одного зайнятого

\begin{tabular}{|c|c|c|c|c|c|}
\hline Період & $\begin{array}{l}\text { Поточ } \\
\text { ний } \\
\text { номер } \\
\text { період } \\
\mathrm{y}, t_{i}\end{array}$ & $\begin{array}{l}\text { Tеоретичне } \\
\text { оплатиення } \\
\text { найманих працівників } \\
\text { у розрахунку на } \\
\text { одного зайнятого, грн, } \\
\hat{y}_{i}\end{array}$ & $t_{10 ; 0,05} S_{\hat{y}_{i}} \mathrm{Q}$ & $\hat{y}_{i}-t_{10 ; 0,05} S_{\hat{y}_{i}} Q$ & $\hat{y}_{i}+t_{10 ; 0,05} S_{\hat{y}_{i}} \mathrm{Q}$ \\
\hline I кв. 2020 & 13 & 28879,4 & 2224,6 & 26654,8 & 31103,9 \\
\hline II кв. 2020 & 14 & 29905,6 & 2302,2 & 27603,4 & 32207,8 \\
\hline III кв. 2020 & 15 & 30931,9 & 2387,8 & 28544,0 & 33319,7 \\
\hline IV кв. 2020 & 16 & 31958,1 & 2480,6 & 29477,5 & 34438,7 \\
\hline
\end{tabular}

Джерело: складено автором

За даними табл. 6 прогнозовані значення оплати праці найманих працівників у розрахунку на одного зайнятого у I-IV кварталах 2020 р. будуть знаходитися в межах:

26655 грн $\leq \hat{y}_{\mathrm{I} \mathrm{кв.2020}} \leq 31103$ грн;

27603 грн $\leq \hat{y}_{\text {II кв.2020 }} \leq 32207$ грн;

28544 грн $\leq \hat{y}_{\text {III кв.2020 }} \leq 33320$ грн;

29477 грн $\leq \hat{y}_{\mathrm{IV}}$ кв.2020 $\leq 34439$ грн. 
Динаміка оплати праці найманих працівників у розрахунку на одного зайнятого поквартально за 2017-2019 pр., а також теоретичні й прогнозні значення, визначені на основі регресійного аналізу на I-IV квартали 2020 р. та їх довірчі інтервали зображені на рис. 2.

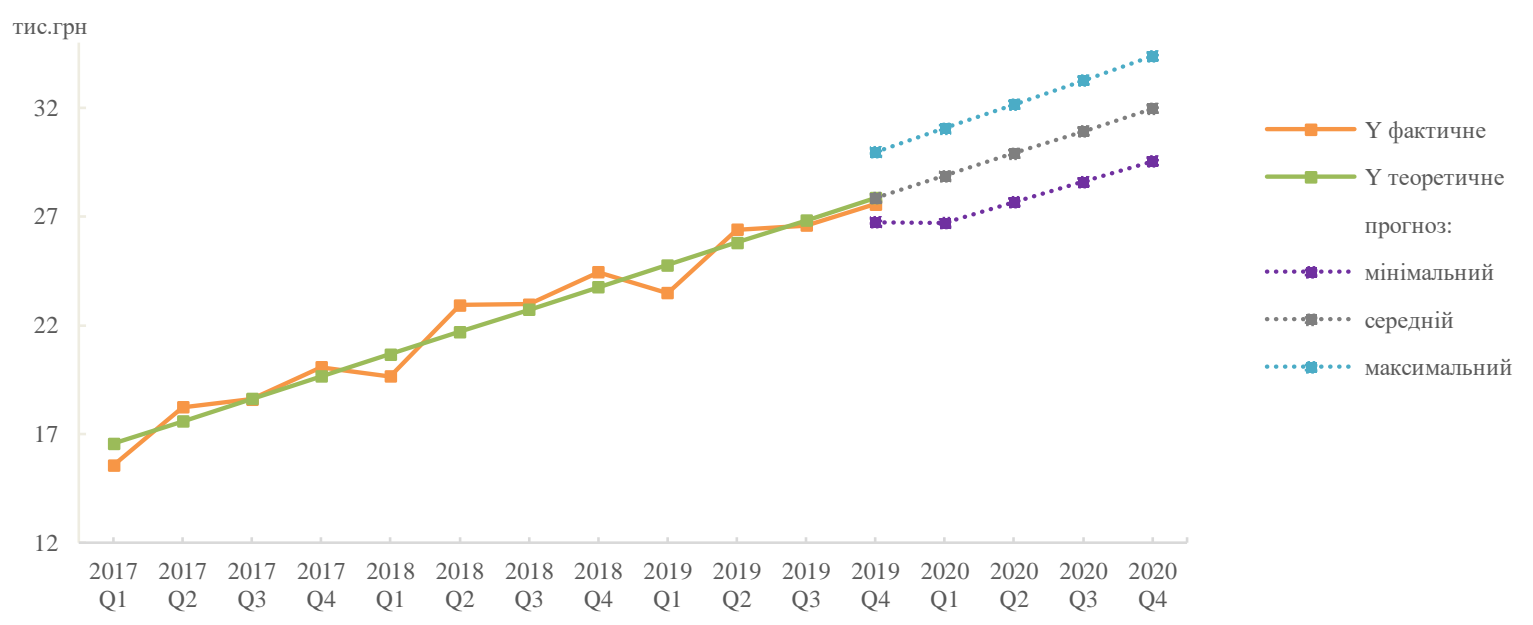

Рис. 2. Динаміка фактичних і прогнозованих значень оплати праці найманих працівників у розрахунку на одного зайнятого в Україні щоквартально у 2017-2020 pр. Джерело: побудовано автором

Отже, у прогнозованому періоді I-IV кв. 2020 р. збережеться тенденція до стійкого збільшення оплати праці найманих працівників у розрахунку на одного зайнятого. У I кв. 2020 р. iї можливий максимальний розмір (за умови незмінності комплексу умов розвитку) буде доходити до 31103 грн, у II кв. 2020 р. - до 32207 грн, у III кв. 2020 р. до 33320 грн та у IV кв. 2020 р. - до 34439 грн.

Проте, враховуючи рівень інфляції, яка в 2019 році становила 4,1\% (див. табл. 1), а у 2020 р. за даними Держстату України - 5\%, необхідно зазначити, що фактичні та прогнозовані значення рівня оплати праці у розрахунку на одного зайнятого в Україні не забезпечують реалізацію права на достатній життєвий рівень працівника і його сім'ї.

Таким чином, очевидно, що для прогнозування економічних процесів потрібно використовувати якісні методи поряд з кількісними прогнозами, саме експертна оцінка дозволить врахувати останні актуальні процеси, що відбуваються в економіці. Методи ж екстраполяції бажано використовувати при прогнозуванні в тих випадках, коли результативна ознака не залежить від інфляції і економічної політики держави та інших складових.

\section{ВИСНОВКИ ТА ПЕРСПЕКТИВИ ПОДАЛЬШИХ ДОСЛІДЖЕНЬ}

Аналіз фактичних даних за період 2017-2019 рр. поквартально та результати прогнозування показників рівня життя населення на I-IV кв. 2020 р., дають підстави зробити висновок, що в Україні зберігається позитивна тенденція до покращення значень показників рівня життя населення. Однак варто врахувати, що світова пандемія 2020 р. внесла свої корективи у соціально-економічний розвиток держав, що позначилося і на рівні та якості життя населення. Тому подальшими науковими розвідками в цьому напрямі $є$ статистичне вивчення та розробка достатньо чисельної кількості статистичних показників, що формують рівень та якість життя населення, порівняння отриманих прогнозованих результатів з фактично досягнутими, розрахунок похибок прогнозу та 
проведення розрахунків на основі як парних, так і множинних рівнянь регресії 3 урахуванням сезонної компоненти.

\section{СПИСОК ВИКОРИСТАНИХ ДЖЕРЕЛ}

1. OECD Framework for Statistics on the Distribution of Household Income, Consumption and Wealth. DOI: https://doi.org/10.1787/9789264194830-en

2. Кулинич Р. О. Статистична оцінка чинників соціально-економічного розвитку : монографія. К. : Знання, 2007. $311 \mathrm{c.}$

3. Єріна А. М., Пальян 3. О. Теорія статистики : практикум. К. : Знання, 2006. 255 с.

4. Ковтун Н. В. Теорія статистики : підручник. К. : Знання, 2012. 399 с.

5. Human Development Report 2020. The next frontier Human development and the Anthropocene. URL: http://hdr.undp.org/en/2020-report

6. Регіональний людський розвиток : стат. зб. / Державна служба статистики України. Київ : “Держаналітінформ”, 2018. 72 с

7. Національні рахунки України за 2018 рік : стат. зб. / Державна служба статистики України. Київ : ДП “Інформ.-аналіт. агентство”, 2020. 248 с.

8. Праця України у 2019 році : стат. зб. / Державна служба статистики України. Київ : ТОВ “Август Трейд”, 2020. 267 с.

9. Індекси споживчих цін за 2019 рік : стат. зб. / Державна служба статистики України. Київ : “Держаналітінформ”, 2020. 181 с.

10. Державна служба статистики України : офіційний вебсайт Державної служби статистики України. URL: http://ukrstat.gov.ua.

11. Статистика: учеб./И.И. Елисеева и др. М. : ТК Велби, Изд-во Проспект, 2005. 448 с.

12. Silvija Vlah Jerić, Davor Zoričić, Denis Dolinar. Analysis of forecasts of GDP growth and inflation for the Croatian economy. Economic Research-Ekonomska Istraživanja. 2020. Vol. 33, № 1. DOI: https://doi.org/10.1080/1331677X.2019.1632727. 


\section{Заец Светлана Владимировна}

кандидат экономических наук, доцент,

доцент кафедры статистики и демографии,

Киевский национальный университет имени Тараса Шевченко,

Киев, Украина

ORCID ID: 0000-0002-6133-1087

e-mail:zsv@bigmir.net

\section{СТАТИСТИЧЕСКОЕ ПРОГНОЗИРОВАНИЕ ПОКАЗАТЕЛЕЙ УРОВНЯ ЖИЗНИ НАСЕЛЕНИЯ В КОНТЕКСТЕ УСТОЙЧИВОГО РАЗВИТИЯ}

Аннотация. В статье исследована сущность и значение прогнозирования основных показателей уровня жизни населения для формирования устойчивого экономического развития страны.

Статистическое прогнозирование уровня жизни населения является информационной базой для определения целей и направлений социально-экономического развития страны, разработки ориентировочных макроэкономических параметров, а также их обоснования и принятия управленческих решений по достижению желаемого уровня жизни населения.

Исходной базой для прогнозирования уровня жизни населения, определения основных направлений развития страны является предложенная система статистических показателей уровня жизни населения Украины за 2010-2019 гг. Основными из них являются макроэкономические показатели, такие как: валовой внутренний продукт в расчете на душу населения, индекс инфляции, средняя продолжительность жизни, индекс человеческого развития и др.

Методологической основой исследования является широко известный метод корреляционнорегрессионного анализа. Регрессионный анализ проведен на основе построенных уравнений регрессии для каждой из исследуемых зависимых переменных величин. В частности, статистической базой для прогнозирования уровня жизни населения в контексте устойчивого экономического развития стали два ключевые макроэкономические индикатора - валовой внутренний продукт в расчете на одного занятого и оплата труда наемных работников в расчете в расчете на одного занятого. В статье обоснована целесообразность статистического прогнозирования этих индикаторов для исследования перспектив развития уровня жизни в стране.

Валовой внутренний продукт отражает состояние экономики в государстве и используется для оценки результатов производства и потребления, темпов экономического роста, производительности труда, а также формирует представление об общем материальном благосостоянии населения. Уровень заработной платы как социально-экономическая категория является основным источником доходов занятого населения и в значительной степени характеризует материальное положение членов общества.

Практические результаты прогнозирования уровня жизни являются основой для обоснования и принятия управленческих решений по дальнейшему социально-экономическому развитию страны. Определены доверительные интервалы, в которых будет находиться объем валового внутреннего продукта в расчете в расчете на одного занятого и размер оплаты труда наемных работников в расчете на одного занятого в Украине в 2020 г.

Сегодня в условиях неопределенности и быстрых изменений внешней и внутренней среды важно предусмотреть возможные варианты развития ключевых показателей уровня жизни населения и уметь предотвратить наступление возможных нежелательных последствий и тенденций мировой пандемии, которая началась в 2020 году.

Ключевые слова: уровень жизни; качество жизни; благосостояние; валовой внутренний продукт; оплата труда; прогнозирование; регрессионный анализ; корреляционный анализ. 


\author{
Svitlana Zaiets \\ $\mathrm{PhD}$ (Economics), Associate Professor, \\ Associate Professor of Statistics and Demography Department, \\ Taras Shevchenko National University of Kyiv, \\ Kyiv, Ukraine \\ ORCID ID: 0000-0002-6133-1087 \\ e-mail: zsv@bigmir.net
}

\title{
STATISTICAL FORECASTING OF STANDARD OF LIVING IN THE CONTEXT OF SUSTAINABLE DEVELOPMENT
}

Abstract. The article examines the essence and importance of forecasting the main indicators of standard of living for the formation of sustainable economic development of the country.

Statistical forecasting of standard of living is an information base for determining the goals and directions of socio-economic development of a country, for development of indicative macroeconomic parameters and their justification, as well as management decisions to achieve the desired standard of living.

The input data for forecasting the standard of living of the population, determining the main directions of development of the country is the proposed system of statistical indicators of standard of living of the population of Ukraine for 2010-2019. The main ones are such macroeconomic indicators as: gross domestic product per capita, inflation rate, an average life expectancy, human development index, etc.

The methodological basis of the study is a well-known method of correlation-regression analysis. The regression analysis was performed on the basis of the constructed regression equations for each of the investigated dependent variables. In particular, the statistical basis for forecasting standard of living in the context of sustainable development were two key macroeconomic indicators - gross domestic product for one person employed and the payment for one employee. The expediency of statistical forecasting of these indicators for prospect development research of standard of living in the country is substantiated.

Gross domestic product reflects the state of the economy in a country and is used to assess the results of production and consumption, economic growth, labor productivity, as well as forms an idea of the general material welfare of the population. The level of wages as a socio-economic category is the main source of income of the employed of the population and largely characterizes the material condition of members of society.

The practical results of forecasting the standard of living are the basis for substantiation and management decisions for further socio-economic development of the country. It has been determined the limits within which the volume of gross domestic product for one person employed and the payment for one employee in Ukraine in 2020 will be located.

Today, in conditions of uncertainty and rapid changes in the internal and external environment, it is important to anticipate possible options for the development of key indicators of standard of living and be able to prevent possible adverse effects and trends of the global pandemic that began in 2020 .

Keywords: standard of living; quality of life; welfare; gross domestic product; salary; forecasting; regression analysis; correlation analysis.

\section{REFERENCES}

1. OECD (2013) Framework for Statistics on the Distribution of Household Income, Consumption and Wealth. OECD Publishing, Paris. DOI: https://doi.org/10.1787/9789264194830-en. [in English].

2. Kulynych, R. O. (2007). Statystychna otsinka chynnykiv sotsialno-ekonomichnoho rozvytku [Statistical evaluation factors of socio-economic development], Kyiv: Znannia Ukraine [in Ukrainian].

3. Yerina, A. M., Palian, Z. O. (2006). Teoriya statystyky [Theory of Statistics]. Kyiv: Znannya [in Ukrainian].

4. Kovtun N. V. (2012). Teoriya statystyky [Statistics theory]. Kyiv: Znannya [in Ukrainian].

5. Human Development Report. The official website. Retrieved from: http://hdr.undp.org/en/indicators/137506 [in English].

6. Rehionalnyi liudskyi rozvytok: stat. zb. [Regional human development]. (2018). Derzhavna sluzhba statystyky Ukrainy. Kyiv [in Ukrainian]. 
7. Natsionalni rakhunky Ukrainy za 2018 rik: stat. zb. (2020). Derzhavna sluzhba statystyky Ukrainy. Kyiv: DP "Inform.-analit. ahentstvo" [in Ukrainian].

8. Pratsia Ukrainy u 2019 rotsi: stat. zb. (2020). Derzhavna sluzhba statystyky Ukrainy. Kyiv: TOV "Avhust Treid" [in Ukrainian].

9. Indeksy spozhyvchykh tsin za 2019 rik: stat. zb. (2020). Derzhavna sluzhba statystyky Ukrainy. Kyiv. [in Ukrainian].

10. Ofitsiinyi veb-sait Derzhavnoi sluzhby statystyky Ukrainy [Official website of State Statistics Service of Ukraine]. www.ukrstat.gov.ua. Retrieved from http://www.ukrstat.gov.ua [in Ukrainian].

11. Statystyka (2005) [Statistics], Prospekt, Moscow, Russia. [in Russian].

Silvija Vlah Jerić, Davor Zoričić, Denis Dolinar. Analysis of forecasts of GDP growth and inflation for the Croatian economy. Economic Research-Ekonomska Istraživanja. 2020. Vol. 33, № 1. DOI: https://doi.org/10.1080/1331677X.2019.1632727. [in English]. 